\title{
Pimpinella Treatment on Reducing Apoptosis of Kidney Cells Following UVB Radiation in Rats
}

\author{
Taufiqurrachman Nasihun ${ }^{1, *}$, Eni Widayati ${ }^{2}$
}

Taufiqurrachman Nasihun ${ }^{1, *}$, Eni Widayati $^{2}$

'Department of Biochemistry, Medical Faculty, Sultan Agung Islamic University, Semarang, Central Java, INDONESIA. ${ }^{2}$ Department of Chemistry, Medical Faculty, Sultan Agung Islamic University, Central Java, INDONESIA.

\section{Correspondence}

\section{Taufiqurrachman Nasihun}

Department of Biochemistry, Medical Faculty, Sultan Agung Islamic University, Semarang, Central Java, INDONESIA.

E-mail: taufiq_rn@yahoo.com

History

- Submission Date: 03-02-2020;

- Review completed: 24-02-2020;

- Accepted Date: 10-03-2020.

DOI : 10.5530/pj.2020.12.77

Article Available online http://www.phcogj.com/v12/i3

Copyright

(C) 2020 Phcogj.Com. This is an openaccess article distributed under the terms of the Creative Commons Attribution 4.0 International license.

\section{ABSTRACT}

Introduction: Pimpinella alpina Molk (PM) is a botanical antioxidant was able to inhibit apoptosis in various cells. Apoptosis is a leading cause of tubular atrophy and therefore chronic kidney disease. However, the effect of PM on reducing apoptosis in kidney cells remains unclear. Objective: aim of this study to elucidate the effect of PM on reducing apoptosis in kidney cells. Methods: In the post test only control group design, 35 male rats were grouped into 7 comprise: NC-G, samples were neither exposure to UVB nor PM treatment; NG-7 and NG-15, all samples were only exposure to UVB irradiation for 7 days; P10-7, P15-7, P10-15, P15-15 groups, samples were exposure to UVB for 7 days and treated with PM for 7 and 15 days respectively. Bax and Caspase 3 expression were assessed by rt-PCR and IHC staining method. Results: Statistical analysis showed that RNA-Bax and RNA-caspase3, Bax and caspase3 protein expression in P15-7, P10-15 and P15-15 were lower significantly compared to those of NG-7, p<0.05, and no significant difference compared to those of NC-G, p $>0.05$. Conclusion: PM treatment with 100 and $150 \mathrm{mg} /$ day for seven and fifteen days were able to decrease Bax and Caspase 3 expression in kidney cells following UVB irradiation. Even, the decreased in Bax and caspase 3 expression were comparable to normal.

Key words: Pimpinella alpina Molk, Kidney Cells, Apoptosis, Bax, Caspase3.

\section{INTRODUCTION}

The Ultraviolet B of sunlight ( 295 to $320 \mathrm{~nm}$ ) is the most powerful and major contributor to damaging skin such as sunburn, inflammation, photo aging, and photocarcinogenesis..$^{1-3}$ The cellular mechanism of skin damages which is induced by UVB has been established. There are growing evidences that UVB can induce reactive oxygen species (ROS), DNA fragmentation, and apoptosis of keratosit skin cells. ${ }^{4}$ The prominence ROS which is generated by skin following UVB irradiation is oxygen superoxide $\left(\mathrm{O}_{2}^{-}\right)$and hydrogen peroxide $\left(\mathrm{H}_{2} \mathrm{O}_{2}\right)$ resulted from mitochondrial oxidative phosphorylation. ${ }^{5}$ Subsequently, $\mathrm{H}_{2} \mathrm{O}_{2}$ is promptly distributed in systemic blood stream and immediately reduced to $\mathrm{OH}^{\circledR}$ by the reaction of Fenton or Heber-Weis. ${ }^{6}$ Radical hydroxyl $\left(\mathrm{OH}^{*}\right)$ is the most dangerous and devastating ROS due to its velocity to react against protein, nucleic acid, lipid membrane, and other molecules of cell which in turn induce DNA fragmentation and apoptosis. In addition to $\mathrm{OH}^{\circ}$, $\mathrm{O}_{2}^{-}$also constitutes a second dangerous ROS owing to its capability to stimulate ferritin, lactoferin, and transferin to release $\mathrm{Fe}$ and produce $\mathrm{OH}^{*}$ via Fenton reaction. ${ }^{7}$ Consequently, DNA fragmentation, apoptosis, and cell losses triggered by UVB may be experienced by a variety of deeper organ including kidney. ${ }^{6}$ Numerous evidences point out that daily intake of flavonoids from plants is able to inhibit apoptosis in various cells including liver, penis, and prostate. $5,8,9$

Pimpinella alpina Molk (PM), is a botanical antioxidant and phytoandrogen containing flavonoids and stigmasterol that has conventionally been used to increase vitality and rejuvenation tonic for adult and old male in Indonesia. ${ }^{9}$ Several studies pointed out that PM treatment in rats have been proven able to ameliorate oxidative stress and impede apoptosis in liver, prostate, penile cells. ${ }^{9-11}$ The oxidative stress improvement was characterized by increased in glutathione peroxidase (GPx) and decreased in xanthine oxidase (XO), whereas inhibiting various tissues apoptosis marked by decreased in RNA Bax and caspase3, and increase in Bcl-2.9,10 However, the effect of PM on reducing apoptosis in kidney cells remain unclear.

According to the comprehensive meta-analysis on chronic kidney disease (CDK), the incidence of CKD worldwide is ranging from $11 \%-13 \% .^{7}$ Aside from as an accelerator of cardiovascular risk, CKD also cause decrease in renal function and to be a predictor of hospitalization, ${ }^{12}$ cognitive dysfunction, ${ }^{13}$ and poor quality of life. ${ }^{14} \mathrm{CDK}$ is characterized by the existing protein within urine (proteinuria) and or reducing glomerular filtration rate (GFR).$^{15}$ Accordingly, the degree of kidney damage originated from CKD can be determined using protein (albumin) to creatinine ratio and may be estimated from creatinine concentration. ${ }^{7}$ Pathogenesis of CKD is determined by glomerular pathology namely tubular atrophy, constituting the important hallmark of CKD. ${ }^{15}$ Tubular atrophy can be defined as the vanishing of any single tubular epithelial cells or whole epithelial cells of tubules and often in conjunction with interstitial fibrosis. ${ }^{7}$ To date, there are numerous evidences obtained from mice model that programmed cell death is a leading reason of tubular atrophy. An 
experimental study was published by Khan et al. demonstrated that tubular atrophy of local and segmental glomerulosclerosis is preceded by apoptosis. ${ }^{16}$ Moreover, a study was completed by Grgic, et al. also pointed out that treatment with sub lethal diphtheria toxin in mouse that has been genetically engineered to express the simian diphtheria toxin receptor completely in kidney epithelial cells, induced tubule cell apoptosis. ${ }^{17}$ It is implied that apoptosis constitutes major contributor to progressive kidney disease, particularly tubular atrophy.

Apoptosis in the life system is utilized to portray the intrinsic cell death program to set off unwanted cells during normal development. Apoptosis also have a pivotal role in tissue regeneration and remodeling in response to damage throughout the lifespan of organism. ${ }^{18,19}$ Accordingly, when apoptosis function does not work appropriately abnormal development, cancer, and degenerative diseases may be occurred. There are numerous evidences that apoptosis can be induced by ROS, for example a study was reported by Pierce GB has shown that $\mathrm{H}_{2} \mathrm{O}_{2}$ is able to induce apoptosis and can be prevented by catalase. ${ }^{20}$ In normal condition low ambient level of ROS is required for preserve physiological functions, including proliferation, cells protection, cellular communication, and gene expression. ${ }^{21}$ On the other hand, at higher concentrations of ROS within cells may injure component of cell targets, such as lipids membrane via lipid peroxidation, DNA, and protein structure, give rise apoptosis. ${ }^{22}$

Apoptosis occur following UVB irradiation is exerted by dependent caspase models comprise intrinsic and extrinsic pathways. ${ }^{15,23}$ In the intrinsic apoptosis, process is initiated by alteration of mitochondrial potential membrane following acquire apoptotic stimuli. Subsequently, mitochondria lose their membrane integrity and induce releasing of cytochrome $c$ which in turn stimulates procaspase 9 and caspase 3 produce DNA disintegration and cell death. ${ }^{1,4}$ Alternatively, in the extrinsic apoptosis, process is induced by the activation of FAS/ CD95, by which initiator caspase8 is activated following formation the CD95 death inducing signaling complex (DISC) which activates caspase8 serve as an initiator caspase. The actuated caspase8 directly activate caspase 3 or indirectly cleave $\mathrm{Bid}$ (Bcl2 interacting domain) into truncated Bid (tBid). Subsequently, tBid move to mitochondria and induce cytochrome $\mathrm{c}$ release and therefore activates caspase 9 and caspase 3 as executioner caspase. ${ }^{1,4}$

Considering, PM has antioxidant properties, therefore using PM to protects kidney cells from ROS attack is a rational choice. Objective of this study is to elucidate the PM effect on reducing apoptosis in kidney cells following UVB radiation.

\section{METHODS}

In the posttest only control group design, 35 male rats of Sprague Dawley (SD) strain, 6 months aged, and 250-300 gram Body Weight (BW), were grouped into 7 comprising: Normal control group (NC-G), Negative control group consist of NG-7 and NG-15, and PM treatment group consisting of four groups: PM10-7, PM15-7, P10-15, and P15-15. In NC-G, rats were neither exposure to UVB nor PM treatment. In both NG-7 and NG-15, rats were only exposure to UVB for 7 days, however, in NG-15 the 7 days left was utilized to restore damaging cell caused by the prior UVB irradiation. In PM treatment group all samples were exposure to UVB for 7 days and treated with PM100 and $150 \mathrm{mg}$ doses per day for 7 (P10-7 \& P15-\&) and 15 days (P10-15 \& P15-15) orally. All rats were preserved in adaptation for one week with environmental temperature $\left(20^{\circ}-24^{\circ} \mathrm{C}\right)$, stable wetness $(55-60 \%)$, and restricted photoperiod ( $12 \mathrm{~h}$ daylight and $12 \mathrm{~h}$ shady) properties before starting treatment. All samples in each group obtain standard nutritional (Ain 93) and water adlibitum during the study. Kidney organ sample from rats were taken and RNA Bax and Caspase 3 was isolated and measured by rt-PCR. Moreover, expression of Bax and caspase 3 was also identified with immunohistochemical (IHC) stain method. Measurement of kidney apoptosis was performed at Gajah Mada University laboratory Yogyakarta. The study has been run following agreed by the Ethical Commission of Sultan Agung Islamic University.

\section{Pimpinella extraction}

The whole plant of PM was elicited from Wonosobo Dieng Plateau Central Java was extracted by the Soxhlet method and dissolved with ethanol. Subsequently, by rotary evaporator, ethanol was disappeared yielding a minor part of extracted plant material and used for treatment. The 100 and $150 \mathrm{mg}$ dose of PM was utilized in the present study is corresponded to the previous study. ${ }^{10,11}$

\section{UVB radiation}

The FS72T12-UVB-H fluorescent lamp that capable of radiating spectra from 280-320 nm was used as sources of ultraviolet light. The average strength of UVB flux which is calculated by UV light meter YK-35UV at cage floor was $9.3 \mathrm{j} / \mathrm{m} 2 / \mathrm{sec}$. All shaved rats in 7 groups were sited in cage floor and irradiated to $1.6 \mathrm{~kJ} / \mathrm{M} 2$ for 10 minutes daily designed for 7 days.

\section{Identification of Bax and Caspase 3 expression by $\mathrm{IHC}$}

In IHC stain method, by deparaffining process slides were prepared for 110 minutes, after that the slides were deep in Mayer Hematoxylin stain for 6 minutes. Following that, slide was cleaned by irrigation of tap water, dried out, cleaned, and mounted. Bax and caspase 3 expression were calculated utilize light microscope at 400-time magnification.

\section{Assessment of Bax and Caspase 3 Expression with rt-PCR}

Rt-PCR is a highly method of molecular biology utilized to identify protein on the level of gen structure and or expression ${ }^{24}$. In rt-PCR method, RNA extraction kit was used to withdraw total RNA from tissue samples in accordance with the Favorgen manufacturer instruction. The rt-PCR was performed by Exicycler ${ }^{\text {Tx}} 96$ Bioneer machine with the SYBR Green dye. Reaction of the rt-PCR were undertaken with a succeeding initial denaturation at $94^{\circ} \mathrm{C}$ for ten minutes in the first cycle complete to 40 cycles and then detained for 30 seconds at to each temperature level. The PCR amplification of Bax used forward and reverse primers 5'ATGTTTTCTGACGGCAACTTC-3' (Bax forward primer) and 5'-AGTCCAATGTCCAGCCCAT-3' (Bax reverse primer) with 133 PCR fragments (bp) respectively. Meanwhile, for PCR amplification of caspase 3 utilized forward and reverse primers 5'-TGTTTGTGTGCTTCTGAGCC-3' (caspase3 forward primer) and 5'-CACGCCATGTCATCATCAAC-3' (caspase3 reverse primer) with 210 PCR fragments (bp) respectively. As a final point, analysis of melting curve was performed over a slope extending from an annealing to a denaturation temperature. The relative standard curve method of quantification was used to consider protein expression and reported as a fold change of gene expression.

\section{Statistical analysis}

The entire number of Bax and Caspase 3 expression were designed and presented as the mean \pm SD. Anova statistical analysis was used to consider the significant differences amongst groups and followed by Post Hoc LSD analysis to determine the significant difference between two groups. The result of statistical analysis was significant if $p<0.05$.

\section{RESULTS}

Following PM treatment for 7 and 15 days, RNA Bax and caspase 3 was isolated from kidney cell and protein expression of Bax and caspase 3 in kidney cells were identified with rt-PCR and IHC staining method respectively at day 8 and 16. The results of the rt-PCR and IHC measurement are summarized in Table 1. 
Table 1: Mean of Bax and Caspase3 Expression in Kidney following PM Treatment.

\begin{tabular}{|c|c|c|c|c|c|c|c|c|}
\hline \multirow[b]{2}{*}{ Variables } & \multicolumn{7}{|c|}{ Groups } & \multirow{2}{*}{$\begin{array}{c}P \\
\text { (Anova) }\end{array}$} \\
\hline & $\begin{array}{c}\text { NC-G } \\
N=5 X \pm S D\end{array}$ & $\begin{array}{c}N G-7 \\
N=5 \quad X \pm S D\end{array}$ & $\begin{array}{c}N G-15 \\
N=5 X \pm S D\end{array}$ & $\begin{array}{c}P 10-7 \\
N=5 X \pm S D\end{array}$ & $\begin{array}{c}P 15-7 \\
N=5 X \pm S D\end{array}$ & $\begin{array}{c}P 10-15 \\
N=5 X \pm S D\end{array}$ & $\begin{array}{c}P 15-15 \\
N=5 X \pm S D\end{array}$ & \\
\hline $\begin{array}{l}\text { RNABax } \\
(\Sigma)\end{array}$ & $\begin{array}{c}8.058 \\
(0.478)\end{array}$ & $\begin{array}{l}27.336 \\
(3.742)\end{array}$ & $\begin{array}{l}21.444 \\
(1.060)\end{array}$ & $\begin{array}{l}14.004 \\
(0.998)\end{array}$ & $\begin{array}{l}12.598 \\
(1.482)\end{array}$ & $\begin{array}{l}10.814 \\
(0.706)\end{array}$ & $\begin{array}{c}7.526 \\
(1.423)\end{array}$ & 0.000 \\
\hline $\begin{array}{c}\text { IHC Bax } \\
(\%)\end{array}$ & $\begin{array}{c}0.800 \\
(0.447)\end{array}$ & $\begin{array}{c}2.800 \\
(0.447)\end{array}$ & $\begin{array}{c}2.400 \\
(0.547)\end{array}$ & $\begin{array}{c}2.000 \\
(0.707)\end{array}$ & $\begin{array}{c}0.800 \\
(1.095)\end{array}$ & $\begin{array}{c}0.600 \\
(0.547)\end{array}$ & $\begin{array}{c}0.600 \\
(0.447)\end{array}$ & 0.000 \\
\hline $\begin{array}{c}\text { RNACaspase3 } \\
(\Sigma)\end{array}$ & $\begin{array}{l}13.070 \\
(2.531)\end{array}$ & $\begin{array}{l}22.802 \\
(4.290)\end{array}$ & $\begin{array}{l}15.504 \\
(2.595)\end{array}$ & $\begin{array}{l}11.692 \\
(1.245)\end{array}$ & $\begin{array}{l}10.800 \\
(0.615)\end{array}$ & $\begin{array}{l}10.382 \\
(0.644)\end{array}$ & $\begin{array}{c}7.328 \\
(0.453)\end{array}$ & 0.000 \\
\hline $\begin{array}{c}\text { IHC Caspase3 } \\
(\%)\end{array}$ & $\begin{array}{c}1.400 \\
(0.894)\end{array}$ & $\begin{array}{c}2.800 \\
(0.447)\end{array}$ & $\begin{array}{c}1.400 \\
(0.547)\end{array}$ & $\begin{array}{c}1.200 \\
(0.447)\end{array}$ & $\begin{array}{c}0.800 \\
(1.095)\end{array}$ & $\begin{array}{c}0.600 \\
(0.547)\end{array}$ & $\begin{array}{c}0.800 \\
(0.836)\end{array}$ & 0.001 \\
\hline
\end{tabular}

The result of the present study pointed out that the highest expression of RNA-Bax was in NG-7, followed by NG-15, P10-7, P15-7, P10-15, NC-G, and the lowest was in P15-15. Meanwhile, the highest RNA caspase 3 expression was in NG-7, followed by NC-G, NG-15, P10-7, P15-7, P10-15, and the lowest was in P15-15. Likewise, by measurement of IHC stained method on Bax and Caspase 3 expression showed the highest was in NG-7, followed by NG-15, P10-7, P15-7, NC-G, and the lowest was in P10-15 and P15-15. Moreover, the highest expression of Caspase 3 protein was in NG-7, followed by NC-G, NG-15, P10-7, P157, P10-15, and the lowest was in P15-15. Anova analysis demonstrated that RNA Bax and caspase 3 measured by rt-PCR and protein expression of Bax and Caspase 3 assessed by IHC amongst group were significant different, $p<0.05$. In order to recognize the difference expression of Bax and caspase 3 between two group will be described below.

\section{RNA BAX expression}

By Post Hoc LSD statistical analysis, RNA Bax expression in NG-7 was higher compared to that of NC-G, $p<0.05$. Expression of RNA Bax in P10-7, P15-7, P10-15, and P15-15 was significantly lower compared to that of NG-7 and NG-15, $p<0.05$ respectively. Meanwhile, RNA Bax expression in NG-15 was significantly lower compared to that of NG-7, $p<0.05$. Moreover, RNA Bax expression in P15-15 was lower significantly compared to that of P10-15, P15-7, P10-7, $p<0.05$. However, when compared to NC-G, the difference of RNA Bax in P1515 was not significant, $p>0.05$ (Figure 1 ).

\section{RNA Caspase3 expression}

The result of statistical analysis showed that RNA caspase 3 in NG-7 was significant higher compared to that of NC-G, $p<0.05$. Expression of RNA caspase 3 in P10-7, P15-7, P10-15, and P15-15 was significantly higher than that of NG-7, $p<0.05$ respectively. RNA caspase 3 expression in NG-15 was significantly lower than that of NG-7, $p<0.05$. Moreover, appearance of RNA caspase 3 in P15-15 was significant lower equated to that of P10-15, P15-7, P10-7, and NC-G, $p<0.05$ (Figure 1)

\section{Expression of Bax protein}

Statistical analysis using Post Hoc LSD on protein expression of Bax pointed out that in NG-7 and NG-15 was significantly higher than that of NC-G, $p<0.05$. In P15-7, P10-15, and P15-15 Bax expression was significantly lower than that of NG-7 and NG-15, $p<0.05$. However, Bax appearance in NG-7 and NG-15 had no significant difference, $p>$ 0.05. Moreover, in P15-7, P10-15, and P15-15 Bax protein expression had no significantly difference when compared to that of NC-G, $p>$ 0.05 (Figures 2 and 3).

\section{Expression of Caspase3 protein}

The result of Post Hoc statistical analysis demonstrated that expression of caspase3 protein in NG-7 was higher than that of NC-G, $p<0.05$. However, when compared to NG-15, the difference expression of capase 3 protein in Nor-G did not exist, $p>0.05$. Caspase 3 protein in
NG-15 was significantly lower than that of NG-7, $p<0.05$. Furthermore, caspase 3 protein in $\mathrm{P} 10-7, \mathrm{P} 15-7, \mathrm{P} 10-15$, and $\mathrm{P} 15-15$ was significantly lower than that of NG-7, $p<0.05$, whereas compared to that of NG-15 the significant difference did not exist, $p>0.05$. Caspase3 in P150-15, P10-15, and P15-7 was not significantly higher than that of NC-G, $p>$ 0.05 (Figures 2 and 3).

\section{DISCUSSION}

In the present study pointed out that UVB irradiation during ten minutes per day for seven days works appropriately induce apoptosis in kidney cells, albeit UVB irradiation was done on skin. It was characterized by the increase in protein expression of Bax and caspase- 3 in negative control group compared to that of normal group. As hypothesized previously, UVB irradiation was capable of increasing $\mathrm{H}_{2} \mathrm{O}_{2}$ level, by which ROS production particularly $\mathrm{OH}^{\bullet}$ can be stimulated following circulated in systemic blood stream. ${ }^{7,11}$ It is also supported by another study was published by Shahzad M et al. demonstrated that $\mathrm{H}_{2} \mathrm{O}_{2}$ was able to induce nephrotoxicity, oxidative stress, apoptosis, and reduced cell survival. These oxidative stress and apoptosis were facilitated by enhancing protein pro apoptosis Bax and down-regulated anti-apoptosis such as Bcl-xL. ${ }^{25}$ The result of the present study was also strengthened by the past study that UVB irradiation was capable of inducing apoptosis in liver cells interceded by ROS particularly $\mathrm{O}^{-}$and $\mathrm{OH}^{\cdot 11}$. $\mathrm{O}^{-}$and $\mathrm{OH}^{\cdot}$ free radicals are resulted from Fenton reaction of circulated $\mathrm{H}_{2} \mathrm{O}_{2}$ derived from UVB irradiation on skin. ${ }^{26,27}$ The increment of $\mathrm{H}_{2} \mathrm{O}_{2}$ concentration following UVB exposure was supported by a study published by Chang and colleague. ${ }^{28}$ Subsequently, $\mathrm{H}_{2} \mathrm{O}_{2}$ is converted to $\mathrm{OH}^{*}$ via Fenton reaction triggered by enhancement of $\mathrm{Fe}$ concentration released from ferritin, lactoferin, and transferrin induced by $\mathrm{O} 2^{-28}$. Moreover, $\mathrm{OH}^{\cdot}$ instantaneously induced oxidative stress characterized by the increment level of MDA and 8-OHdG, in contrary the decrement of total antioxidant capacity (TAC) and GPx activity and eventually DNA fragmentation and apoptosis. ${ }^{6,26}$

In the present study PM treatment with $150 \mathrm{mg}$ /day for seven days and $100 \mathrm{mg}$ and $150 \mathrm{mg} /$ day for 15 days could ameliorate apoptosis in kidney cells characterized by down-regulated protein pro-apoptosis Bax and caspase 3 . The decrease in Bax and Caspase 3 expression in the 100 and $150 \mathrm{mg}$ dose per day, both for 7- and 15-days treatment were equivalent to normal. In the present study Bax and caspase 3 expression is in line with the study was published by Widayati et al. demonstrated that treatment of PM with 100 and $150 \mathrm{mg}$ dose/day was able to decrease Bax and Caspase 3 expression in liver cells following exposure to UVB light. ${ }^{11}$ In this study also demonstrated that decrease in Bax and Caspase 3 expression was preceded by improvement of stress oxidative characterized by increased in superoxydedismuatase (SOD), catalase (CAT), and glutathion peroxidase (GPx) activities, and decreased in xanthin oxidase (XO), 8-hydroxy-2-deoxyguanosine (8-OHdG) and Malondialdehyde (MDA). ${ }^{10,11}$ It was plausible, considering apoptosis induced by UVB radiation is heralded by rigorous oxidative stress. ${ }^{23}$ 


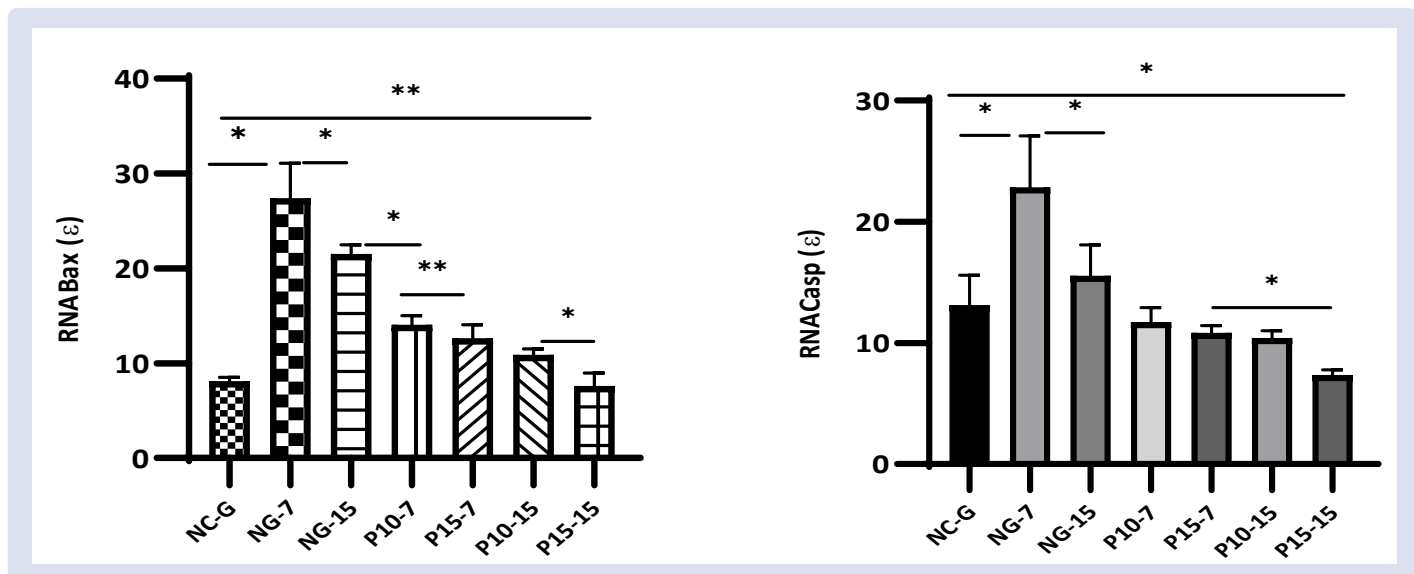

Figure 1: Bax and Caspase3 Expressions following PM Treatment in each group, measured by rtPCR. Post Hoc analysis: ${ }^{*} P<0.05,{ }^{* *} P>0.05$.

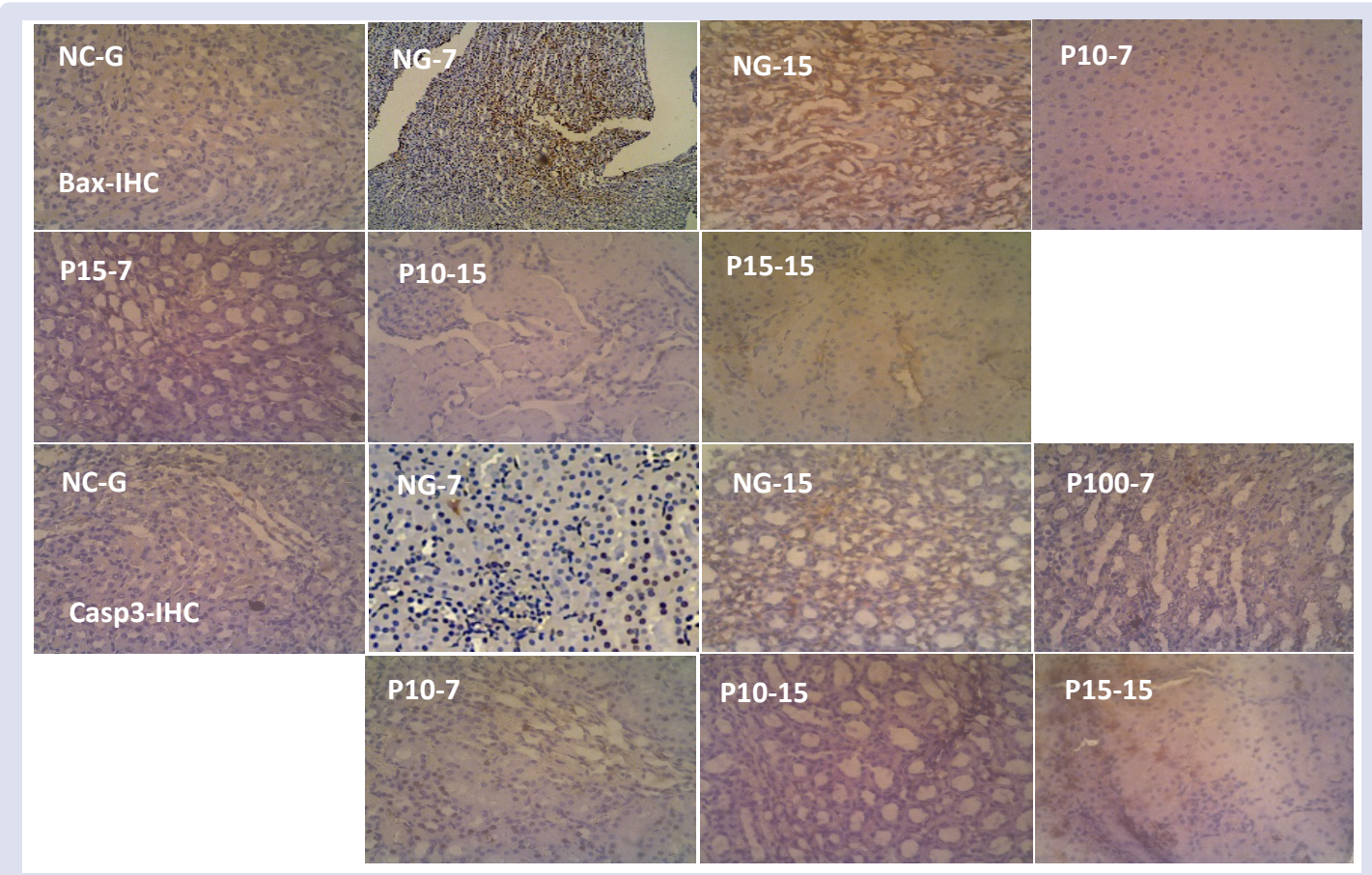

Figure 2: Bax and Caspase-3 Expression following Treatment in each group, measured by IHC stain methods.

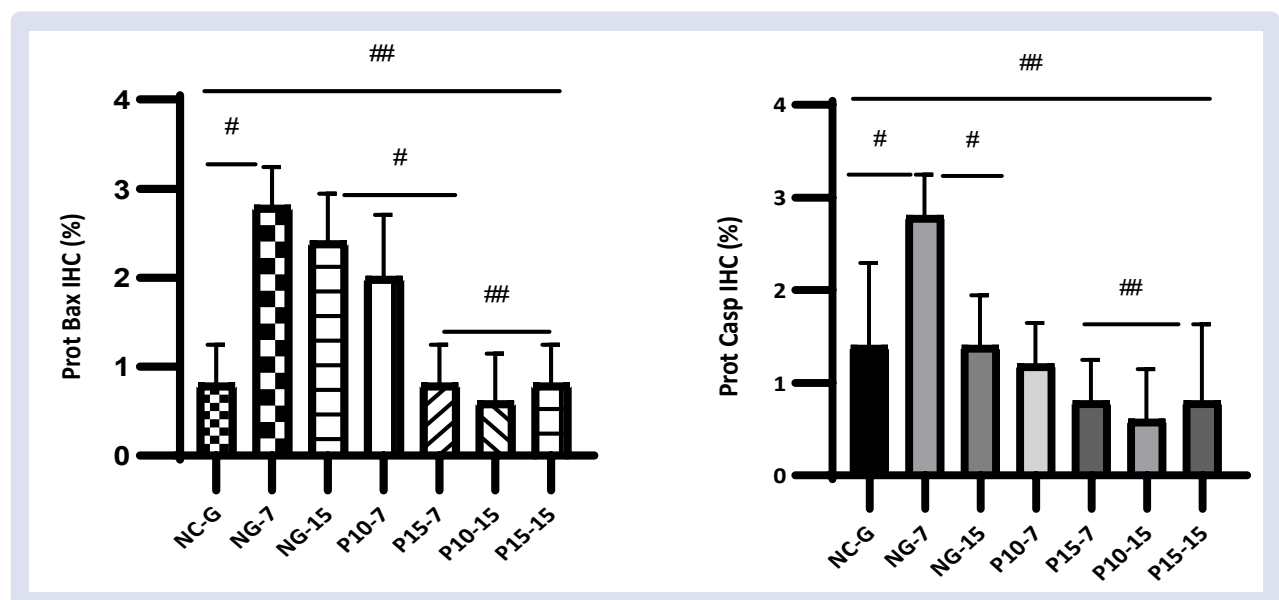

Figure 3: Bax and Caspase3 Expressions following Treatment in each group, measured by $\mathrm{IHC}$ stain methods. ${ }^{\#} p<0.05 ; \# P>0.05$. 


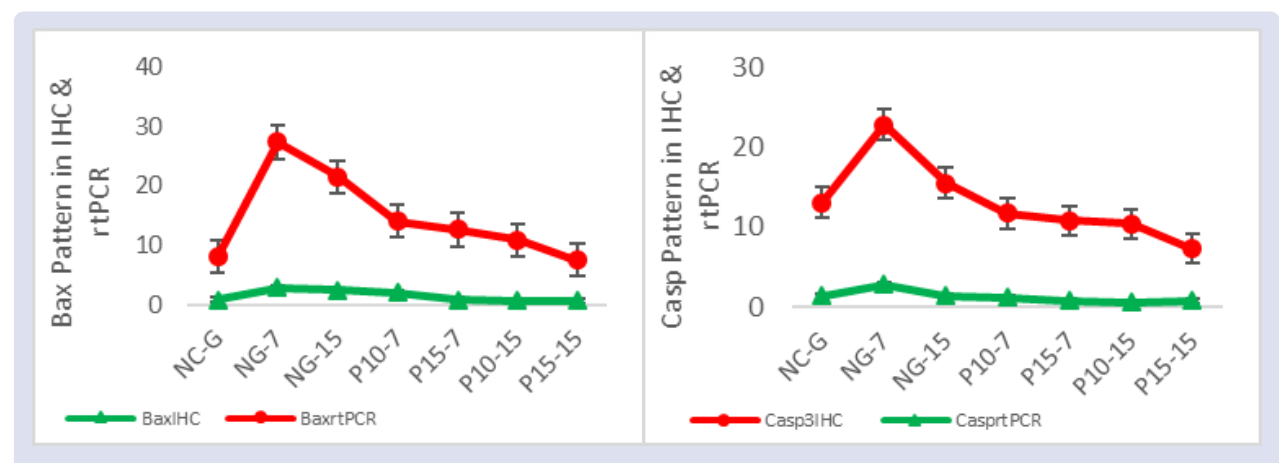

Figure 4: Pattern of Bax and caspase 3 in IHC stain methods and rtPCR in each group.

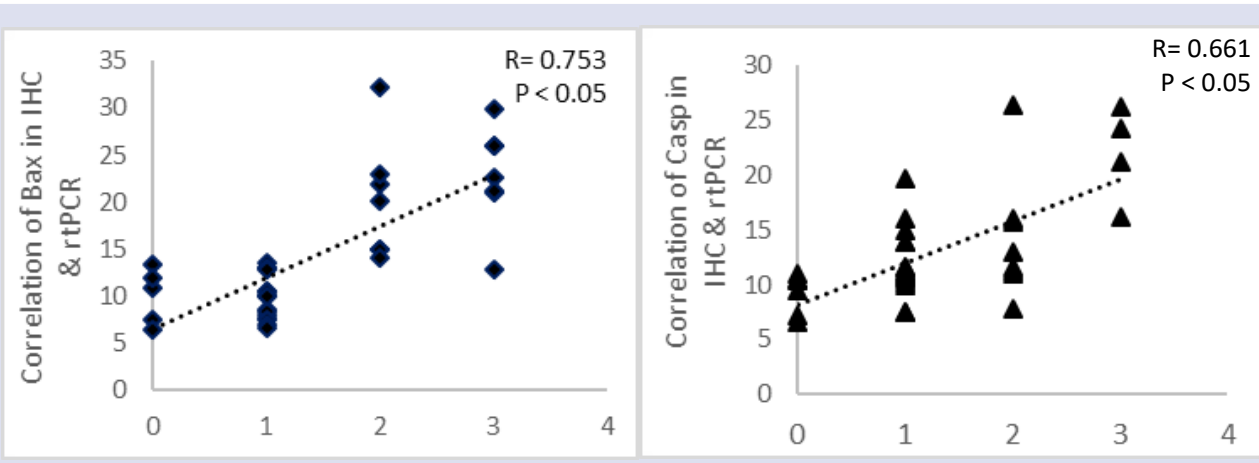

Figure 5: Pearson Correlation of Bax and caspase3 Expression result from IHC stain methods and rt-PCR.

Improvement of Apoptosis in kidney cells was induced by UVB irradiation following treatment of PM may be mediated by stigmasterol and flavonoids contained in Pimpinella alpine Molk. Stigmasterol is an androgen derive from plant that have been proven capable of increasing testosterone concentration and inhibition of apoptosis in Sprague Dawley male's prostate and penile cells of rat model. It was plausible, since testosterone is anti-apoptosis owing to its capability to increase Bcl-2 and decrease caspase 3 expression. ${ }^{9,10} \mathrm{Bcl}-2$ is an antiapoptosis along with $\mathrm{Bax}$ as pro-apoptosis protein have critical role in cellular apoptosis regulation, particularly using intrinsic pathway mediated by alteration of mitochondrial permeability and therefore cytochrome $\mathrm{c}$ release. ${ }^{29}$ In this context following UVB radiation, ratio of $\mathrm{Bax} / \mathrm{Bcl}-2$ was increased and lead to apoptosis. Conversely, following $\mathrm{PM}$ treatment $\mathrm{Bax} / \mathrm{Bcl}-2$ ratio was decreased and lead to inhibition of apoptosis. In addition, flavonoids have been documented was able to reduce oxidative stress characterized by the enhancement of SOD, GPx, CAT activities, and decreased in activity of $\mathrm{XO}$, concentration of MDA and 8-OHdG which in turn reduce apoptosis. ${ }^{8,10,11}$

In the present study apoptosis was measured by rt-PCR and IHC stain method. Rt-PCR was used to identify RNA Bax and caspase 3 expression isolated from kidney cells, meanwhile IHC was used to identify protein expression of Bax and caspase 3 taken from kidney cells. In the present study expression of Bax and caspase 3 was recognized by both rt-PCR and IHC methods have similar pattern, increased and decreased in Bax and caspase 3 expression tend in parallel fashion (Figure 4). In addition, RNA Bax expression and protein expression of Bax have strong correlation $(\mathrm{r}=0.753 ; p<0.05)$. Similarly, RNA caspase-3 expression and protein expression of caspase 3 also have positive correlation $(\mathrm{r}=$ 0.661; $P<0.05$ ) (Figure 5). These results suggested that both rt-PCR and IHC staining method are appropriate to measure expression of Bax and caspase 3 as marker of apoptosis cells. Finally, the result of the present study, treatment of PM particularly in $100 \mathrm{mg}$ dose per day for 15 days and $150 \mathrm{mg}$ dose per day for 7 and 15 days could improve apoptosis in kidney cells characterized by decrease in RNA and protein expression of Bax and caspase3. Moreover, the decrease in apoptosis marker as mentioned above was comparable to normal.

\section{CONCLUSION}

In summary, treatment of PM with 100 and $150 \mathrm{mg}$ daily dose for seven and fifteen days could reduce Bax and Caspase 3 protein expression in kidney cells following UVB radiation. Even the decrease in protein Bax and caspase 3 was comparable to normal condition.

\section{ACKNOWLEDGEMENTS}

Sultan Agung Islamic University support and funding this research.

\section{CONFLICTS OF INTEREST}

No conflict of interest to be declared related to data collection, statistical analysis, writing of the manuscript, and publish the results.

\section{REFERENCES}

1. Zhai Y, Dang Y, Gao W, Zhang Y, Xu P, Gu J, et al. P38 and JNK signal pathways are involved in the regulation of phlorizin against UVB-induced skin damage. Experimental Dermatology. 2015;24:275-9.

2. Zhan JYX, Wang XF, Liu YH, Zhang ZB, Wang L, Chen JN, et al. Andrographolide Sodium Bisulfate Prevents UV-Induced Skin Photoaging through Inhibiting Oxidative Stress and Inflammation. Mediators of Inflammation. 2016;1-12.

3. Tuchinda C, Lim HW, Strickland FM, Guzma'n EA, Wong HK. Comparison of broadband UVB, narrowband UVB, broadband UVA and UVA1 on activation of apoptotic pathways in human peripheral blood mononuclear cells. Photodermatol Photoimmunol Photomed. 2007;23:2-9.

4. Peng $C$, Wang $X$, Chen J Jiao R, Wang L, LiYM, et al. Biology of Ageing and Role of Dietary Antioxidants. BioMed Research International. 2014;1-13.

5. Nasihun T, Widayati E. Administration of Purwoceng (Pimpinellaalpina Molk) Improves Oxidative Stress Biomarker Following UVC Irradiationin SpargueDawley Male Rats. Journal of Natural Remedies. 2016;15:82-91.

6. Lipinski B. Hydroxyl Radical and Its Scavengers in Health and Disease. Oxid Med Cell Longev. 2011;809696

7. Hill NR, Fatoba ST, Oke JL, Hirst JA, Christopher O'Callaghan CA, et al. Global Prevalence of Chronic Kidney Disease A Systematic Review and Meta-Analysis. PLOS ONE. 2016;1-118. 
8. Nehlig A. The neuroprotective effects of cocoa flavanol and its influence on cognitive performance. Br J Clin Pharmacol. 2012;75(3):716-27.

9. Taufiqurrachman. The effect of buceng extracts on androgen production in Sprague Dawley male rats. Medical Journal of Indonesia. 2012;21(1):29-31.

10. Nasihun T. Increase in $\mathrm{Bcl} 2$ expression of penile and prostate cells of Sprague Dawley male rats following treatment with buceng (combination of Pimpinella alpina molk with Eurycoma longifolia Jack). Med J Indones. 2015;24:8-13.

11. Widayati E, Nasihun T. Treatment of Pimpinella Alpina Molk Improve Oxidative stress and Inhibit Liver Cellular Apoptosis in Rats Following UVB Irradiation: Is there Any Correlation? Bangladesh Journal of Medical Science. 2018;17(01):11828.

12. Gansevoort RT, Correa-Rotter R, Hemmelgarn BR, Jafar TH, Heerspink HJ, Mann JF, et al. Chronic kidney disease and cardiovascular risk: epidemiology, mechanisms, and prevention. Lancet. 2013.

13. Etgen T, Chonchol M, Forstl H, Sander D. Chronic Kidney Disease and Cognitive Impairment: A Systematic Review and Meta-Analysis. American Journal of Nephrology. 2012;35(5):474-82.

14. Perlman RL, Finkelstein FO, Liu L, Roys E, Kiser M, Eisele G, et al. Quality of life in chronic kidney disease (CKD): a cross sectional analysis in the Renal Research Institute-CKD study. Am J Kidney Dis. 2005;45(4):658-66.

15. Schelling JR. Tubular atrophy in the pathogenesis of chronic kidney disease progression. Pediatr Nephrol. 2016;31:693-706.

16. Khan S, Cleveland RP, Koch CJ, Schelling JR. Hypoxia induces renal tubular epithelial cell apoptosis in chronic renal disease. Lab Invest. 1999;79:1089-99.

17. Grgic I, Campanholle G, Bijol V, Wang C, Sabbisetti VS, Ichimura T, Humphreys $\mathrm{BD}$, Bonventre JV. Targeted proximal tubule injury triggers interstitial fibrosis and glomerulosclerosis. Kidney Int. 2012;82:172-83.
18. Ho J. The regulation of apoptosis in kidney development: implications for nephron number and pattern? Frontiersin Pediatrics. 2014;2(128):1-6.

19. Taylor RC, Cullen SP, Martin SJ. Apoptosis: controlled demolition at the cellular level. Nat Rev Mol Cell Biol. 2008;9(3):231-41.

20. Pierce GB, Parchment RE, Lewellyn AL. Hydrogen peroxide as a mediator of programmed cell death in the blastocyst. Differentiation. 1991;46:181-6.

21. Droge W. Free radicals in the physiological control of cell function. Physiological Reviews. 2002;82(1):47-95.

22. Vallon V. The proximal tubule in the pathophysiology of the diabetic kidney. Am Physiol Regul Integr Comp Physiol. 2011;300:R1009-22.

23. Nasihun T, Widayati E. Administration of Purwoceng (Pimpinellaalpina Molk) Improves Oxidative Stress Biomarker Following UVC Irradiationin SpargueDawley Male Rats. Journal of Natural Remedies. 2016;15:82-91.

24. Sękalska B, Ciechanowicz A, Dołęgowska B. Biochem Genet. 2006;44:129

25. Shahzad M, Small DM, Morais C, Wojcikowski K, Shabbir A, Gob GC. Protection against oxidative stress-induced apoptosis in kidney epithelium by Angelica and Astragalus. Journal of Ethnopharmacology. 2016;179:412-9.

26. Salucci S, Burattini S, Battistelli M, Baldassarri V, Maltarello MC, Falcieri E. Ultraviolet B (UVB) Irradiation-Induced Apoptosis in Various Cell Lineages in Vitro. Int J Mol Sci. 2013;14:532-46.

27. Hattori $Y$, Nishigori C, Tanaka T, Uchida K, Nikaido O, et al. 8-Hydroxy-2'Deoxyguanosme Is Increased in Epidermal Cells of Hairless Mice after Chronic Ultraviolet B Exposure. J Invest Dermatol. 1997;107:733-7.

28. Chang $\mathrm{H}$, Oehrl W, Elsner $\mathrm{P}$, Thiele JJ. The role of $\mathrm{H} 2 \mathrm{O} 2$ as a mediator of UVBinduced Apoptosis in Keratinocytes. Free Radical Research. 2003;37:655-63.

29. Birben E, Sahiner UM, Sackesen C, Erzurum S, Kalayci O. Oxidative stress and antioxidant defense. WAO Journal. 2012;5:9-19.

\section{GRAPHICAL ABSTRACT}
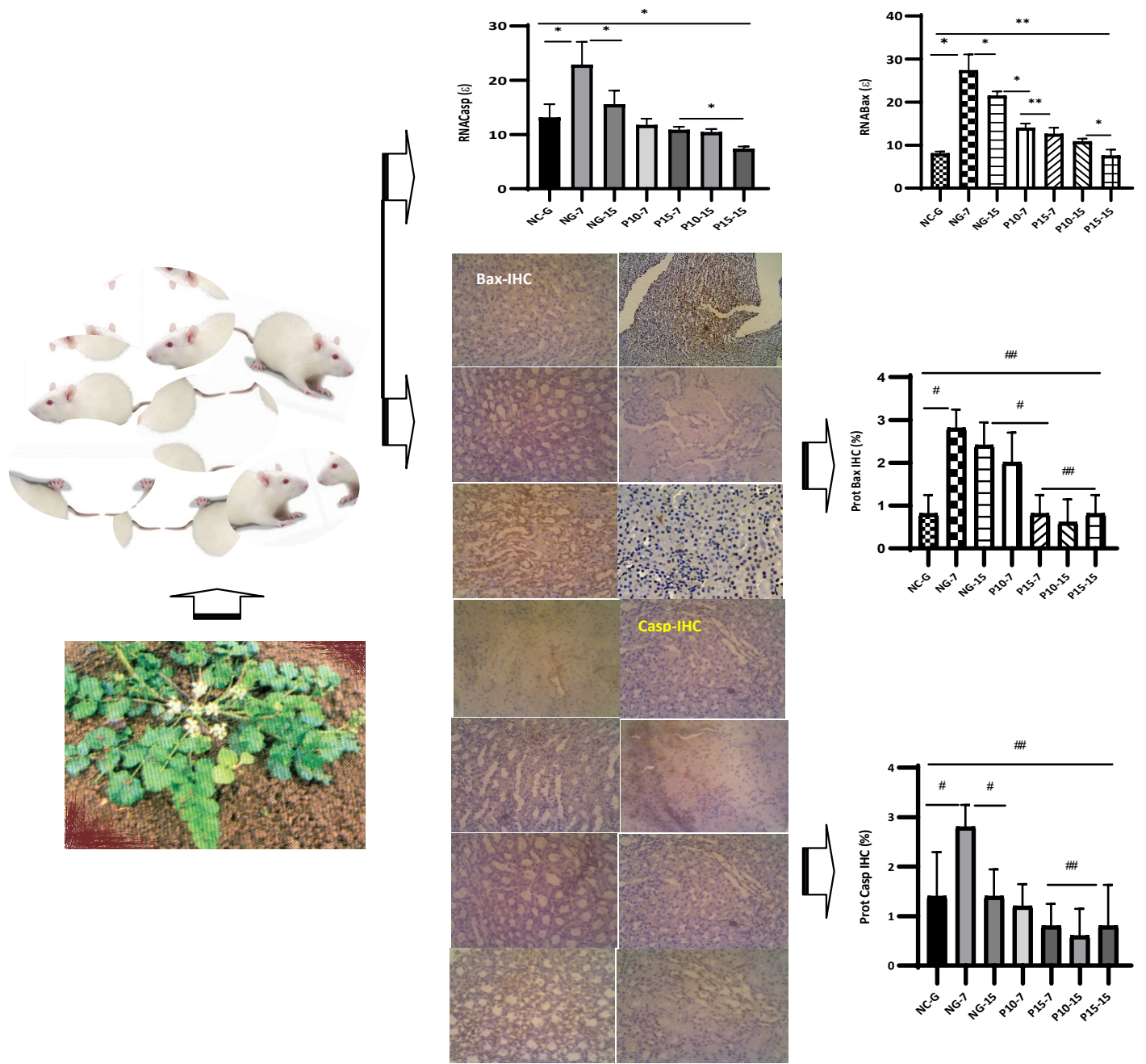


\section{ABOUT AUTHORS}

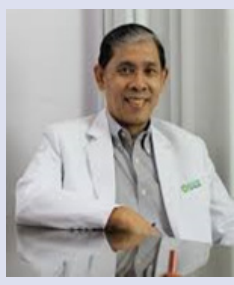

Taufiqurrachman Nasihun, Professor in medical sciences. Received his doctoral degree at Diponegoro university Semarang in 2007. He is specialist in andrology, consultant in sex and antiaging medicine, and concern in medical biochemistry. He is also lecturer in medical biochemtery of medical faculty, Universitas Islam Sultan Agung and reseacher in botanical product and antioxidant.

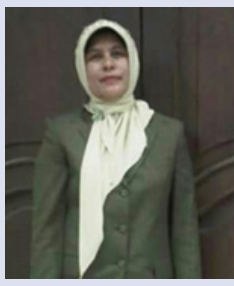

Eni Widayati, received her Master of Chemistry at Gajahmada University Yogyakarta in 1995. She is currently a lecturer at Universitas Islam Sultan Agung Semarang Indonesia. Her research interests are medicinal chemistry and antioxidant.

Cite this article: Nasihun T, Widayati E. Pimpinella Treatment on Reducing Apoptosis of Kidney Cells Following UVB Radiation in Rats. Pharmacogn J. 2020;12(3):503-9. 